\title{
Investigating the Influence of Financial Development Indicators on Economic Growth: Evidence from South Asia
}

\author{
Muhammad Tahir ${ }^{1,2}$, Khizar Hayat ${ }^{3} \&$ Nisar Ahmad ${ }^{2,3}$ \\ ${ }^{1}$ School of Accounting, RMIT University, Melbourne, Australia \\ ${ }^{2}$ Hailey College of Commerce, University of the Punjab, Lahore, Pakistan \\ ${ }^{3}$ Government College University, Lahore, Pakistan \\ Correspondence: Muhammad Tahir, School of Accounting, RMIT University, Melbourne, Australia.
}

Received: March 26, 2018

doi:10.5430/afr.v7n3p9
Accepted: April 22, 2018

Online Published: April 29, 2018

\begin{abstract}
The study empirically investigates the influence of financial development on economic growth in South Asia by using six indicators of financial development, which include Gross Fixed Capital Formation (GFCP), Broad Money (M2), Domestic Credit to Private Sector (DCPS), Market Capitalization (MC), Trade Openness (TO) and Foreign Direct Investment (FDI). While Economic Growth is measured by Real Gross Domestic Product per Capita (GDP). For this purpose, the study used panel data from "World Development Indicators" for the period of 1980-2015 of six major South Asian countries, which include Pakistan, India, Bangladesh, Bhutan, Sri Lanka and Nepal. These countries have common feature of being under-developed. The study shows its uniqueness by considering six under-developed South Asian countries and applying three result estimation techniques, which include Pooled Mean Group (PMG), The Mean Group (MG) and The Dynamic Fixed Effect (DFE). Different results were produced through these three techniques. The final conclusion was drawn on the basis of Hausman test; that is PMG model estimation technique. The unit root test was also applied to check stationarity. The long-run results of PMG model show significance of all independent variables, while short-run results state insignificance of all independent variables except FDI. The results are consistent with the literature. Along with other recommendations, the study, especially, focuses that the trade barriers should be removed among South Asian countries as trade openness has a positive influence on economic growth. It will result in more consistent economic growth.
\end{abstract}

Keywords: financial development, economic growth, South Asia, pooled mean group, Hausman test

\section{Introduction}

Establishing the relationship between financial development and economic growth has been of great interest to researchers for few decades. What relationship exists between financial development and economic growth? Whether the direction flows from financial development to economic growth (Mckinnon, 1973; Schumpeter, 1911; Shaw, 1973), or economic growth to financial development (Gurlay \& Shaw, 1955), or, there exists bidirectional relationship (Demetriades \& Hussein, 1996; Luintel \& Khan, 1999), or, they have no relationship (Lucas, 1988; Ram, 1999). How financial development can be measured? How financial development is important for the progress of the country or region? What is the role of financial development in the growth of developed as well as developing countries? These are the appealing questions for researchers.

The roots of finance-growth nexus date back to the pioneer work of Schumpeter (1911), followed by many legendary research works (Arestis \& Demetriades, 1997; Demetriades \& Hussein, 1996; Goldsmith, 1969; Gurlay \& Shaw, 1955; Levine \& Zervos, 1998; Luintel \& Khan, 1999; Mckinnon, 1973; Shaw, 1973). A lot of work on this topic in different economies and time period states the interest of researchers and significance of the study.

The literature suggests four different arguments about the relationship between financial development and economic growth, which include supply leading (finance-led growth), demand following (growth-led finance), response (bidirectional connection) and autonomous (no relationship).

\subsection{Importance for South Asia}

Establishing finance-growth relationship significantly matters for emerging economies. Financial sector of any state is supposed to be the backbone for the development of its economy, for the reason that of its useful contribution in 
accumulating the foreign exchange funds by growing exports and appealing overseas investment. For the collection of foreign reserves, financial segment of the economy is most important. These foreign reserves are compulsory for making and appealing investments (Mckinnon, 1973).

Owing to the above point of view, now, the developing countries government, have accepted the significance of financial segment. Definitely, they are currently committed that economic growth can only be possible with the help of developing financial sector. It has been argued previously that the investment, foreign exchange and exports are considered important terms as regards the financial developments of the economy. The efficient financial sector is pre-requisite to attract foreign investment and to enhance the demand of local manufactured goods in international markets. Consequently, balance of payment becomes favorable, foreign reserves increase and ultimately higher growth rate becomes possible.

An emerging economy needs more reserves. At any cost, government tries to enhance its foreign reserves and these reserves can easily be enhanced by the development in the financial sector of the economy. These reserves can be used to promote local and foreign investment, which will ultimately improve the financial sector.

Government of emerging economies plays an important role to get benefits from above discussed practice. Government should liberalize the trade strategies and accommodate each other by increasing free trade zone to enhance inter country and inter-regional trade. European Union countries follow this technique and getting the advantage of the unrestricted trade zone. Government of emerging economies should follow these activities, of developed economies to enhance trade. So, this process will be helpful to develop financial segment, which in turn increases the economic growth of the country. If emerging economies properly follow this process, they will be included soon in the list of developed economies.

Consequently, the purpose of this research is to investigate the relationship between financial development and economic growth in South Asia. According to the best of our knowledge there in not even a single study which employed these proxies of financial development to check the relationship between variables specifically with respect to the South Asian countries. Moreover, this study will support the economists to know whether these financial development proxies in fact have influence over the growth level in South Asian countries.

The next section will explain the previous relevant studies. The third section will describe the data source, variables and the specific models that will be used for analysis purpose. Afterwards, empirical results will be stated in the next section, which will be followed by the conclusion of the current study. List of the references will be provided in the last section of the study.

\section{Literature Review}

A considerable research has been published on finance-growth nexus. Researchers from various countries have discussed the topic from various perspectives on the bases of availability of data and that of variable into consideration. So, different conclusions have been drawn. For example, Arestis, Demetriades, and Luintel (2001) concluded that stock market development contributes to growth in the long-run but banking sector development contributes fewer fractions in growth. Moreover, Odhiambo (2014) rejects the supply leading hypothesis and accept demand following hypothesis in South African countries. Contrarily, Thangavelu, Jiunn, and James (2004) found that there is a causal relationship between economic developments to financial intermediaries. He also accepted the supply leading phenomenon and rejects the demand following hypothesis in Australia. However, Giannopoulos (2006) found a very weak relationship between variables in Scandinavian countries.

Furthermore, Kabir and Hoque (2007) concluded that broad money and domestic credit to the private sector have negative significant impact on the economic growth. Moreover, it was also argued that during pre-reform period, trade along with FDI had significant negative relation to growth, but now, in post-reform period, same variables have positive significant relation with growth. However, inflation has negative significant relation during pre and post reform period in Bangladesh.

Seetanah, Ramessur, and Rojid (2009) concluded a positive association between financial development and economic growth. However, they also shed light that financial development contributes lesser as compared to other control variables included in the model such as with investment, openness and education in Island economies.

Hung (2009) observed non-linear relationship between finance and growth. He also observed that investment loans stimulate productivity and consumption loans create hurdles in the way of productivity. So productivity depends on the magnitude of these two loan channels. The higher the magnitude of investment loans is, the higher the productivity will be and vice versa. These loan channels depend on intermediation cost, playing a key role, in determining the magnitude of any for any of these. 
Ndako (2010) observed the existence of a supply-leading association in India. He reached this conclusion by looking at financial development and economic growth relation. Furthermore, economic growth has a causal connection with trade and financial developments in the Nigerian economy (Chimobi, 2010). The same conclusion was drawn by Abdulkadhim and Al-Jafari (2014) in the case of Bahrain. However, no causal association among trade openness, financial development and economic growth was observed. Moreover, Choong and Lam (2011) found that there exists an ambiguous connection between FDI and economic growth. FDI's role in increasing or decreasing the growth of the economy depends on financial sector development. They concluded that financial sector expansion is an essential requirement for foreign direct investment to have a productive impact on economic growth. However, in the case of Saudi Arabia, Nasir, Rehman, and Ali (2017) argued that FDI has no link with financial development and economic growth, mainly, because of heavy reliance on oil production by the Saudi Arabia.

In addition to this, Gurgul and Lukasz (2012) concluded that before financial crises there was a causal relationship which passes from stock market development to economic growth and economic growth to development in the banking industry. After the crises, the banking industry has extra influence on economic growth as compared to pre-crises and positive causal relation changed into negative causal relation after the crises in Poland.

Kouki (2013) shed light upon a long-run association between the variables in cross country analyses. He explained that financial institutions and financial markets in Tunisia and Morocco have positive relations with growth. However, increasing the financial services in Egypt will cause development in economic growth. On the other hand, banking system of Algeria has a positive relation to economic growth.

Suliman and Elian (2014) concluded a short-term causal association between FDI and the size of equity market, and between the size of equity market and economic growth. They also shed light upon long-terms integration association between the variables.

Alkhuzaim (2014) shed light upon long-run association between financial sector development and economic progress. $\mathrm{He}$ also observed that there is a bi-directional relationship exist between M2 and real GDP. Whereas unidirectional relationship was observed between credit to private sector and real GDP.

\section{Data and Methodology}

\subsection{Data}

The study used panel data from "World Development Indicators" for the period of 1980-2015 of six major South Asian countries, which include Pakistan, India, Bangladesh, Bhutan, Sri Lanka and Nepal. The study employed the annual data source of "World Development Indicators" as of being an authentic secondary source of data managed by the World Bank. The study used six independent variables and one dependent variable. The independent variables are the indicators of financial development while the dependent variable is the proxy for economic growth. Table 1 below shows the variables' names, their definitions and the specific symbols of the variables used in the current study.

Table 1. Variables with their definitions and symbols

\begin{tabular}{|c|c|c|}
\hline Symbols & Variables & Definitions \\
\hline GDP & Real GDP per Capita & $\begin{array}{l}\text { Annual GDP per capita after removing inflation } \\
\text { effect by dividing with GDP deflator }\end{array}$ \\
\hline GFCF & Gross Fixed Capital Formation & $\begin{array}{l}\text { Annual gross fixed capital formation ratio as } \\
\text { representative of Investment (\% of GDP) }\end{array}$ \\
\hline M2 & Broad Money & Annual broad money ratio (\% of GDP) \\
\hline DCPS & Domestic Credit to Private Sector & Annual credit ratio to private sector (\% of GDP) \\
\hline $\mathrm{MC}$ & Market Capitalization & $\begin{array}{l}\text { Annual market capitalization ratio as representative } \\
\text { of size of stock market development ( } \% \text { of GDP) }\end{array}$ \\
\hline TO & Trade Openness & Trade Percent of GDP \\
\hline FDI & Foreign Direct Investment & Foreign Direct Investment (\% of GDP) \\
\hline
\end{tabular}




\subsection{Model Selection}

There are different empirical approaches to find the finance and growth relationship in previous studies. Previous studies used cross-sectional data and applied Ordinary Least Square (OLS) method of estimation However, some other researchers consider cross-sectional analysis untrustworthy posing issues outlined below:

Firstly, different countries have their own economic assessment tools. If one considers them the same, it may result in sensitivity of sample selection. Secondly, cross-sectional analysis does not take time variable into consideration. Finally, the problem of interconnection cannot be overcome properly in cross-sectional research (Khan \& Senhadji, 2003).

Moreover, Rehman and Ahmad (2016) shed light that these issues cannot be solved by the use of instrumental variables when the results need to be generalized over a longer time period. Furthermore, the use of time-series statistics has not also solved these issues because high frequency data are necessary to increase the power of the time-series econometric method, which bounds the econometric investigation to just a limited economy for which such statistics are available.

To overcome the deficiencies of cross-sectional as well as time-series investigation, researchers gradually turn towards panel data that allows them to integrate time-series and cross-sectional quality and provides a huge variety of econometric estimation approaches (Dawson, 2008). However, the studies based on panel data traditionally used random effect or fixed effect models, or the co-integration technique (Blackburne \& Frank, 2007).

Currently, Rehman and Ahmad (2016) attempt to solve the outstanding problems in the finance-growth relationship. They used panel data based on annual 21 countries' observations covering the period from 1990 to 2013, applying an error correction model based on Pooled Mean Group (PMG) analysis. The uniqueness of this method is that it permits for heterogeneity in parameters in economic growth regressions. Moreover, this method differentiates between the short-run and long-run influence of financial sector development on growth.

There are a number of debates on the association between financial sector development and economic growth. In the following ways, current study pursues to add to the argument on the comprehensive effects of financial sector developments from an empirical view. First, current study adopts the newly established dynamic panel heterogeneity analysis built on the procedure presented by Pesaran, Shin, and Smith (1999). More specially, this study uses the ARDL model, where the estimates are supported by three diverse estimators, namely Pooled Mean Group (PMG), The Mean Group (MG) Model, and The Dynamic Fixed Effect (DFE) Model to observe the influence of financial sector development indicators on economic growth. The application of these estimators allows us to take into account the country-specific heterogeneity problems. To the best of the authors' knowledge, there is very limited research available that have applied these models for panel data in case of South Asian countries. Finally, by applying this methodology technique, the current study also overcomes the problems of cross-sectional and time-series analysis issues. Afterwards, one best estimator will be selected on the basis of Hausman test. STATA and EVIEWS softwares will be used for analyses purpose.

Augmented Dickey-Fuller (ADF) test was applied to check the stationarity of the data. Equation for Augmented Dickey-Fuller Test is as follows:

$$
\Delta Y_{i, t}=\alpha_{i}+\beta_{i} Y_{i, t-1}+\delta_{i} t+\sum_{k=1}^{n} \theta_{i k-} \Delta Y_{i, t-k--}+\mu_{i, t}
$$

Here, $\mathrm{H}_{0}: \beta_{\mathrm{i}}=0$

The above stated null hypothesis states that the unit root exists.

To conclude short-run and long-run influence, ARDL approach is used. Following is the equation for panel ARDL:

$$
Y_{i, t}=\sum_{j=1}^{p} \delta_{i, j} Y_{i, t-j}+\sum_{j=0}^{q} \gamma_{i, j} X_{i . t-j}+\mu_{i}+\varepsilon_{i t}
$$

Where the dependent variable is real GDP per capita.

The specific model for a Pooled Mean Group Estimator is given below:

$$
\Delta y_{i, t}=\theta_{i}\left(E C_{i, t}\right)+\sum_{j=1}^{p-1} \alpha_{i j} \Delta y_{i, t-j}+\sum_{j=0}^{q-1} \varphi_{i, j} \Delta X_{i, t-j}+\varepsilon_{i t}
$$

Where

$$
E C_{i-t}=y_{i, t-1}-X^{\prime}{ }_{i, t} \beta .
$$


The error correction term is shown on the right hand side of the first part of the equation. This part tends to explain the divergence or convergence of the model in the long-run. The negative numeric value states long-run association among variables.

\section{Empirical Results}

\subsection{Descriptive Statistics}

Table 2 below shows the descriptive statistics for the panel data of six countries for the period of 1980-2015. The missing values were imputed using STATA.

Table 2. Descriptive statistics

\begin{tabular}{ccccc}
\hline Variables & Mean & Maximum & Minimum & Std. Dev. \\
\hline GDP & 106.6307 & 1361.02 & 13.29 & 153.7271 \\
GFCF & 24.64369 & 63.04872 & 12.51486 & 9.722915 \\
M2 & 41.61619 & 80.6631 & 14.1969 & 14.74372 \\
DCPS & 23.37028 & 58.77493 & 2.508195 & 11.74888 \\
MC & 16.74357 & 146.8556 & -2.121992 & 17.98859 \\
TO & 28.0766 & 62.9564 & 6.87567 & 13.73379 \\
FDI & 0.707033 & 6.170874 & -0.191275 & 0.827833 \\
\hline
\end{tabular}

\subsection{Results of Unit Root Test}

Table 3 below states the result of ADF test to check the stationarity of the data. All variables are stationary at first difference except GDP and FDI as of being stationary at level.

Table 3. Unit root test

\begin{tabular}{cccc}
\hline Variables & t-statistics & p-value & Conclusion \\
\hline GDP & 66.9165 & 0.0000 & Stationary \\
GFCF & 16.2601 & 0.1796 & Non-Stationary \\
D.GFCF & 118.729 & 0.0000 & Stationary \\
M2 & 5.76 & 0.9277 & Non-Stationary \\
D.M2 & 88.9243 & 0.0000 & Stationary \\
DCPS & 5.75660 & 0.9279 & Non-Stationary \\
D.DCPS & 50.7246 & 0.0000 & Stationary \\
MC & 12.1901 & 0.4305 & Non-Stationary \\
D.MC & 107.320 & 0.0000 & Stationary \\
TO & 15.6244 & 0.2090 & Non-Stationary \\
D.TO & 117.049 & 0.0000 & Stationary \\
FDI & 28.4339 & 0.0048 & Stationary \\
\hline
\end{tabular}

\subsection{Results of Pooled Mean Group (PMG) Model}

Table 4 and 5 below show the results of Pooled Mean Group estimation in the long-run and short-run respectively. In the long-run, all the independent variables have significant influence on the dependent variable because of having p-value less than 0.05. While in the short-run, none of the independent variables put influence on the dependent variable except FDI, as of having a negative effect on GDP. Furthermore, in the long-run, DCPS shows hurdle in the way of economic growth as of having a negative influence on GDP. In addition to this, the coefficient value and the negative sign of the error correction term in Table 5 (coefficient of EC, that is -0.8466) show the power of convergence of the variables towards equilibrium in the long-run, which is also significant. 
Table 4. Pooled mean group test results (Long-run)

\begin{tabular}{cccc}
\hline Variables & Coefficient & Std. Err. & p-value \\
\hline GFCF & 1.210354 & 0.476483 & 0.011 \\
M2 & 3.084504 & 0.659302 & 0.000 \\
DCPS & -2.72359 & 0.68078 & 0.000 \\
MC & 3.55446 & 0.8019 & 0.000 \\
TO & 1.164501 & 0.571296 & 0.042 \\
FDI & 16.08384 & 7.95629 & 0.043 \\
\hline
\end{tabular}

Table 5. Pooled mean group test results (Short-run)

\begin{tabular}{cccc}
\hline Variables & Coefficient & Std. Err. & p-value \\
\hline EC & -0.8466 & 0.094624 & 0.000 \\
GFCF D1 & 2.210646 & 4.551918 & 0.627 \\
M2 D1 & -0.01028 & 4.877267 & 0.998 \\
DCPS D1 & 3.10065 & 4.197724 & 0.460 \\
MC D1 & -1.46194 & 3.427791 & 0.670 \\
TO D1 & 0.700191 & 5.367338 & 0.896 \\
FDI D1 & -19.7646 & 9.504689 & 0.038
\end{tabular}

\subsection{Results of Mean Group (MG) Model}

Table 6 and 7 below show the results of The Mean Group estimation in the long-run and short-run respectively. In the long-run, none of the independent variables, except DCPS, have significant influence on the dependent variable because of having p-value more than 0.05 . While in the short-run, none of the independent variables exerts influence on the dependent variable. In this estimation technique, FDI is also proved to be insignificant in the short-run as opposed to the result generated by the PMG model.

Table 6. Mean group test results (Long-run)

\begin{tabular}{cccc}
\hline Variables & Coefficient & Std. Err. & p-value \\
\hline GFCF & 0.487404 & 2.330306 & 0.834 \\
M2 & 1.667926 & 3.106068 & 0.591 \\
DCPS & -11.715 & 3.970904 & 0.003 \\
MC & 2.98173 & 3.190709 & 0.350 \\
TO & -0.29292 & 2.138091 & 0.891 \\
FDI & 9.991037 & 18.2444 & 0.584 \\
\hline
\end{tabular}

Table 7. Mean group test results (Short-run)

\begin{tabular}{cccc}
\hline Variables & Coefficient & Std. Err. & p-value \\
\hline EC & -1.0455 & 0.056581 & 0.000 \\
GFCF D1 & 6.804226 & 7.157053 & 0.342 \\
M2 D1 & -6.50229 & 5.762232 & 0.259 \\
DCPS D1 & 0.37345 & 6.32745 & 0.953 \\
MC D1 & 0.890647 & 2.755623 & 0.747 \\
TO D1 & 0.878413 & 6.798724 & 0.897 \\
FDI D1 & -23.873 & 18.52 & 0.197 \\
\hline
\end{tabular}




\subsection{Results of Dynamic Fixed Effect (DFE) Model}

Table 8 and 9 below show the results of The Dynamic Fixed Effect estimation in the long-run and short-run respectively. In the long-run, M2 and DCPS do not have an effect on GDP, however, MC and TO have negatively significant effect on GDP along with FDI as having a positive significant influence. While in the short-run, none of the independent variables has influence on the dependent variable except TO, as of having significant negative effect on GDP.

Table 8. Dynamic fixed effect model results (Long-run)

\begin{tabular}{cccc}
\hline Variables & Coefficient & Std. Err. & p-value \\
\hline GFCF & 3.486907 & 2.106218 & 0.098 \\
M2 & 0.934915 & 2.439752 & 0.702 \\
DCPS & 1.063727 & 2.878783 & 0.712 \\
MC & -12.8593 & 3.469105 & 0.000 \\
TO & -6.72283 & 2.827734 & 0.017 \\
FDI & 37.78036 & 18.37746 & 0.040
\end{tabular}

Table 9. Dynamic fixed effect model results (Short-run)

\begin{tabular}{cccc}
\hline Variables & Coefficient & Std. Err. & p-value \\
\hline EC & -1.03402 & 0.081254 & 0.000 \\
GFCF D1 & -1.99282 & 4.059413 & 0.623 \\
M2 D1 & -0.60625 & 4.624106 & 0.896 \\
DCPS D1 & 2.414156 & 4.844472 & 0.618 \\
MC D1 & 0.563064 & 3.306418 & 0.865 \\
TO D1 & -9.18518 & 3.243223 & 0.005 \\
FDI D1 & -8.79398 & 18.32083 & 0.631 \\
\hline
\end{tabular}

\subsection{Hausman Test}

Hausman test is used to check the best estimation out of the applied models. So, after applying PMG and MG model, Hausman test was used. The result of the Hausman test indicates that PMG model (table 4 and table 5) is more significant as compared to MG model (table 6 and table 7). Afterwards, DFE model was applied (table 8 and table 9). Hausman test was again used to check whether PMG or DFE model is more significant in the context of the current study. The result of the Hausman test shows that PMG model is more significant as compared to its counterpart.

\section{Conclusion}

The current study was aimed at investigating the influence of financial development indicators, namely Gross Fixed Capital Formation, Broad Money, Domestic Credit to Private Sector, Market Capitalization, Trade Openness and Foreign Direct Investment, on the economic growth, proxy by Real GDP per Capita of six South Asian countries, which include Pakistan, Bangladesh, Nepal, India, Bhutan and Sri Lanka by considering panel data for the years 1980-2015. The data were taken from "World Development Indicators" as of being a reliable data source, managed by the World Bank.

For analyses purpose, first of all, missing values in data were imputed by using STATA. Afterwards, stationarity was checked by applying unit root tests. GDP and FDI were stationary at level while the rest of the variables were stationary at first difference. The results of panel unit root test provide direction to apply Pooled Mean Group (PMG) model.

The current study applied three estimation techniques, namely Pooled Mean Group (PMG), The Mean Group (MG) and The Dynamic Fixed Effect (DFE). PMG model of estimation was chosen as the best estimation model for this study.

The results of PMG model estimation show long-run and short-run influence of independent variables on the dependent variable. In the long-run, all the indicators of financial development have significant influence on the 
economic growth. Moreover, domestic credit to the private sector is a hurdle in economic growth in the long-run because of having a negative sign with the coefficient.

However, in the short-run, none of the indicators of financial development has a significant effect on the economic growth of the selected South Asian countries except of FDI. But FDI has negative significant influence on GDP in the short-run. In addition to this, the coefficient value and the negative sign of the error correction term show the power of convergence of the variables towards equilibrium in the long-run, which is also significant.

The results are consistent with previous studies (Asghar \& Hussain, 2014; Fang \& Jiang, 2014; Keho, 2017).

After analyzing the results, current study confirms the supply leading hypothesis in South Asian countries in the long-run. However, the current study has following limitations which may undermine the outcomes of this research if would have been considered.

First, the study used only six indicators of financial development. While there may be some other important indicators of financial development which were not considered to see their effect on economic growth. Second, the study used yearly data which were limited to a few years (1980-2015). If data for more years added in analysis of the study, the results may be changed. Third, the current study focused on six South Asian countries. Data of remaining countries can also be utilized to check the relationship between financial developments and economic growth more widely. Fourth, this study considered only WDI database to extract the data of financial development and economic growth, which has some missing values in the data.

Moreover, in the light of results, study suggests that the trade barriers should be removed between South Asian countries because trade openness has a positive impact on economic growth and magnitude of growth can be increased by removing trade barriers. Furthermore, these South Asian countries should declare a tax-free zone to encourage investment in the region to increase economic growth.

\section{References}

Abdulkadhim, H., \& Al-Jafari, M. (2014). Financial Development, Trade Openness and Economic Growth: A Trilateral Analysis of Bahrain, 7.

Alkhuzaim, W. (2014). Degree of Financial Development and Economic Growth in Qatar: Cointegration and Causality Analysis. International Journal of Economics and Finance, 6(6), 57-69. https://doi.org/10.5539/ijef.v6n6p57

Arestis, P., Demetriades, P., \& Luintel, K. (2001). Financial Development and Economic Growth: The Role of Stock Markets. Journal of Money, Credit and Banking, 33(1), 16-41. https://doi.org/10.2307/2673870

Arestis, P., \& Demetriades, P. O. (1997). Financial Development and Economic Growth, Assessing the Evidence. Economic Journal, 107, 783-799. https://doi.org/10.1111/j.1468-0297.1997.tb00043.x

Asghar, N., \& Hussain, Z. (2014). Financial Development, Trade Openness and Economic Growth in Developing Countries: Recent Evidence from Panel Data. Pakistan Economic and Social Review, 52(2), 99-126.

Blackburne, E., \& Frank, M. (2007). Estimation of NonStationary Heterogeneous Panels. Stata Journal, 7(2), 197-208.

Chimobi, O. P. (2010). The Causal Relationship among Financial Development, Trade Openness and Economic Growth in Nigeria. International Journal of Economics and Finance, 2(2), 137-147. https://doi.org/10.5539/ijef.v2n2p137

Choong, C. K., \& Lam, S. Y. (2011). Foreign Direct Investment, Financial Development and Economic Growth: Panel Data Analysis. IUP Journal of Applied Economics, 10(2), 57-73.

Dawson, P. J. (2008). Financial Development and Economic Growth in Developing Countries. Progress in Development Studies, 8(4), 325-331. https://doi.org/10.1177/146499340800800402

Demetriades, P. O., \& Hussein, K. A. (1996). Does Financial Development Cause Economic Growth? Time-Series Evidence from 16 Countries. Journal of Development Economics, 51, 387-411. https://doi.org/10.1016/S0304-3878(96)00421-X

Fang, X., \& Jiang, Y. (2014). The Promoting Effect of Financial Development on Economic Growth: Evidence from China. Emerging Markets Finance and Trade, 50(Supplement 1), 34-50. https://doi.org/10.2753/REE1540-496X5001S103

Giannopoulos, M. P. (2006). Economic Growth and Financial Development: Empirical Analysis of three Scandinavian Countries. Operational Research: An International Journal, 6(2), 221-238. 
https://doi.org/10.1007/BF02941233

Goldsmith, R. W. (1969). Financial Structure and Development: New Haven and London: Yale University Press.

Gurgul, H., \& Lukasz, L. (2012). Financial Development and Economic Growth in Poland in Transition: Causality Analysis. Finance a úvěr-Czech Journal of Economics and Finance, 62(4), 347-367.

Gurlay, J., \& Shaw. (1955). Money in a Theory of Finance. Washington, DC: The Brookings Institution.

Hung, F.-S. (2009). Explaining the Nonlinear Effects of Financial Development on Economic Growth. Journal of Economics, 97, 41-65. https://doi.org/10.1007/s00712-008-0057-4

Kabir, S. H., \& Hoque, H. A. A. B. (2007). Financial Liberalization, Financial Development and Economic Growth: Evidence from Bangladesh. Savings and Development, 31(4), 431-448.

Keho, Y. (2017). The Impact of Trade Openness on Economic Growth: The Case of Cote D'Lvoire. Cogent Economics \& Finance, 5(1). https://doi.org/10.1080/23322039.2017.1332820

Khan, M., \& Senhadji, A. S. (2003). Financial Development and Economic Growth: A Review and New Evidence. Journal of African Economies, 12(Supplement 2), 89-110. https://doi.org/10.1093/jae/12.suppl_2.ii89

Kouki, I. (2013). Financial Development and Economic Growth in the North African Region. African Development Review, 25(4), 551-562. https://doi.org/10.1111/1467-8268.12049

Levine, R., \& Zervos, S. (1998). Capital Control Liberalization and Stock Market Development. World Development, 26(7), 1169-1183. https://doi.org/10.1016/S0305-750X(98)00046-1

Lucas, R. E. (1988). On the Mechanics of Economic Development. Journal of Monetary Economics, 22(1), 3-42. https://doi.org/10.1016/0304-3932(88)90168-7

Luintel, K. B., \& Khan, M. (1999). A Quantitative Reassessment of the Finance-Growth Nexus: Evidence from a Multivariate VAR. Journal of Development Economics, 60, 381-405. https://doi.org/10.1016/S0304-3878(99)00045-0

Mckinnon, R. I. (1973). Money and Capital in Economic Development. Washington, DC: The Brookings Institution.

Nasir, N. M., Rehman, M. Z., \& Ali, N. (2017). Foreign Direct Investment, Financial Development and Economic Growth: Evidence from Saudi Arabia. International Journal of Financial Research, 8(4), 228-239. https://doi.org/10.5430/ijfr.v8n4p228

Ndako, U. B. (2010). Financial Development and Economc Growth: Evidence from Nigeria. The IUP Journal of Financial Economics, 8(4), 37-59.

Odhiambo, N. M. (2014). Financial Systems and Economic Growth in South Africa: A Dynamic Complementarity Test. International Review of Applied Economics, 28(1), 83-101. https://doi.org/10.1080/02692171.2013.828681

Pesaran, M. H., Shin, Y., \& Smith, R. P. (1999). Pooled Mean Group Estimation of Dynamic Heterogeneous Panels. Journal of the American Statistical Association, 94(446), 621-634. https://doi.org/10.1080/01621459.1999.10474156

Ram, R. (1999). Financial Development and Economic Growth: Additional Evidence. The Journal of Development Studies, 35(4), 164-174. https://doi.org/10.1080/00220389908422585

Rehman, S. u., \& Ahmad, H. K. (2016). The Impact of Foreign Capital Inflows on Economic Growth: Pooled Mean Group Analysis for Developing Countries. Pakistan Economic and Social Review, 54(2), 191-203.

Schumpeter, J. (1911). The Theory of Economic Development: Harvard University Press.

Seetanah, B., Ramessur, S. T., \& Rojid, S. (2009). Financial Development and Economic Growth: New Evidence from a Sample of Island. Journal of Economic Studies, 36(2), 124-134. https://doi.org/10.1108/01443580910955033

Shaw, E. S. (1973). Financial Deepening in Economic Development. New York: Oxford University Press.

Suliman, A. H., \& Elian, M. I. (2014). Foreign Direct Investment, Financial Development, and Economic Growth: A Cointegration Model. The Journal of Developing Areas, 48(3), 219-243. https://doi.org/10.1353/jda.2014.0041

Thangavelu, S. M., Jiunn, A. B., \& James. (2004). Financial Development and Economic Growth in Australia: An Empirical Analysis. Empirical Economics, 29, 247-260. https://doi.org/10.1007/s00181-003-0163-7 